\title{
miR-935 Inhibits Oral Squamous Cell Carcinoma and Targets Inositol Polyphosphate-4-phosphatase Type IA (INPP4A)
}

\author{
NOBUYUKI MARUYAMA ${ }^{1}$, MASATO UMIKAWA ${ }^{2}$, HIROFUMI MATSUMOTO ${ }^{3}$, \\ TESSHO MARUYAMA ${ }^{4}$, KAZUHIDE NISHIHARA ${ }^{1,5}$, TOSHIYUKI NAKASONE $^{5}$, \\ AKIRA MATAYOSHI ${ }^{5}$, TAKAHIRO GOTO ${ }^{5}$, FUSAHIRO HIRANO ${ }^{5}$, AKIRA ARASAKI ${ }^{4}$, \\ HIROYUKI NAKAMURA ${ }^{1,5}$, GORO MATSUZAKI ${ }^{4,6}$ and GIICHI TAKAESU ${ }^{4,6}$ \\ ${ }^{1}$ Department of Oral and Maxillofacial Functional Rehabilitation, \\ Graduate School of Medicine, University of the Ryukyus, Nishihara, Japan; \\ ${ }^{2}$ Department of Medical Biochemistry, Graduate School of Medicine, University of the Ryukyus, Nishihara, Japan; \\ ${ }^{3}$ Department of Pathology, Ryukyu University Hospital, Nishihara, Japan; \\ ${ }^{4}$ Molecular Microbiology Group, Tropical Biosphere Research Center, University of the Ryukyus, Nishihara, Japan; \\ ${ }^{5}$ Department of Oral and Maxillofacial Surgery, Ryukyu University Hospital, Nishihara, Japan; \\ ${ }^{6}$ Department of Host Defense, Graduate School of Medicine, University of the Ryukyus, Nishihara, Japan
}

\begin{abstract}
Background/Aim: Oral squamous cell carcinoma (OSCC) is a common malignancy with poor prognosis. Therefore, novel therapeutic options are needed to improve prognosis of OSCC. Recently, microRNAs (miRs) have received increasing attention as a potential therapeutic tool for carcinomas. However, no definitive miR-based drugs for patients with OSCC have been reported to date. The aim of this study was to identify new miRs potentially involved in cellular processes associated with OSCC malignancy, which could lead to novel therapeutic strategies. Materials and Methods: We identified miRs that are modulated in OSCC and possibly regulate OSCC malignancy, using $m i R$ microarray on OSCC cell lines. Results: $m i R-935$ and miR509-3p were down-regulated in OSCC cell lines and patient tissues. When miR-935 was overexpressed in HSC-3-M3 cells, proliferation, migration, and invasion of the cell line was suppressed, whereas apoptosis was increased. Moreover, we showed that the gene inositol polyphosphate-4phosphatase type I A (INPP4A) is a potential target whose expression is positively regulated by $\mathrm{miR}-935$. Conclusion:
\end{abstract}

This article is freely accessible online.

Correspondence to: Tessho Maruyama, Molecular Microbiology Group, Tropical Biosphere Research Center and Department of Host Defense, Graduate School of Medicine, University of the Ryukyus, Senbaru 1, Nishihara, Okinawa 903-0213, Japan. Tel/Fax: +818064906444, e-mail: tesshou.730@gmail.com

Key Words: Microarray, microRNA, miR-935, INPP4A, oral squamous cell carcinoma.
miR-935 may function as a tumor suppressor by inhibiting OSCC malignancy via INPP4A induction. Therefore, miR935 can be a new therapeutic candidate for OSCC treatment.

Oral cavity cancers (including lip cancer) are commonly observed worldwide, and represent the eighteenth-highest number of malignancies with an incidence of 354,864 cases in 2018 (24.4\% of all the head and neck cancers including lip and thyroid) (1, 2). The "Cancer statistics, 2019" estimated 35,130 cases and 7,410 deaths of oral cancers in the United States in 2019 (3), indicating 1.7- and 1.9-fold increases in the numbers compared to the numbers 25 years ago $(3,4)$. Among the head and neck malignancies (including oral cancer), oral squamous cell carcinoma (OSCC) is the most common type (5). Although OSCC can be easily detected because the oral cavity is directly observable, OSCC has a poor prognosis (6). Even after early-stage detection, about $40 \%$ of patients die within 3 years (7). Therefore, development of new therapeutic options is more important for improving prognosis of OSCC than development of diagnostic tools. Actually, many studies regarding OSCC therapy have been reported to date (8-11). Among those, miRs are expected to provide new OSCC therapeutic targets (12-15).

MicroRNAs (miRs) are small (19-25 nucleotides in length), non-coding RNAs known to regulate cancers through gene regulatory networks acting on oncogenes or tumor suppressors (16-18). Approximately 2,700 human miRs have been registered in the miRbase (Release 22.1), the primary public repository and online resource for miRs (19). Many OSCCrelated miRs and related pathways provide insights into the pathogenesis mechanisms and may help develop new therapies $(12,20-22)$. However, miR-derived therapeutics for patients 
with OSCC have not yet been established. Therefore, to identify new miR candidates for OSCC therapy, we performed miR microarray analysis on three different tongue squamous cell carcinoma (SCC) lines. We further conducted in vitro studies to evaluate the anticancer effects of the newly identified miRs.

\section{Materials and Methods}

Human tissue samples. Fresh human OSCC and adjacent matched non-cancer tissues were obtained from surgical resection specimens of patients in the Department of Oral and Maxillofacial Functional Rehabilitation, Ryukyu University Hospital (Okinawa, Japan). The 20 patients had not received chemotherapy and/or radiotherapy before the resection. Tissue samples were immediately placed in RNAlater RNA Stabilization Reagent (Qiagen, Hilden, Germany). The reagents were discarded, and samples were transferred to new tubes for storage at $-80^{\circ} \mathrm{C}$ until the analyses. All subjects gave their informed consent for inclusion before they participated in the study. The study was conducted in accordance with the Declaration of Helsinki, and the protocol was approved by the Ethics Committee of the University of the Ryukyus (Okinawa, Japan) (Project identification code: 939 and 1061).

Cell lines and cultures. OSCC cell lines HSC-3 (JCRB0623, established by F. Momose), HSC-3-M3 (JCRB1354, established by T. Matsui), and SAS (JCRB0260, established by K. Takahashi) were obtained from the Japanese Collection of Research Bioresources Cell Bank (JCRB, Osaka, Japan). The human keratinocyte cell line $\mathrm{HaCaT}$ (23) was obtained from the German Cancer Research Center (DKFZ), Heidelberg, Germany, via the official distributor Cell Lines Service (CLS, Eppelheim, Germany). OSCC cell lines and HaCaT cells were cultured in minimum essential media (Gibco, Thermo Fisher Scientific, Waltham, MA, USA) supplemented with $10 \%$ newborn calf serum (NBCS) (Gibco, Thermo Fisher Scientific) and MG-30 (DMEM High Glucose ready-to-use, with serum) (CLS), respectively. Cells were incubated at $37^{\circ} \mathrm{C}$ in a humidified incubator containing $5 \% \mathrm{CO}_{2}$.

miR microarray. HSC-3, HSC-3-M3, SAS, and HaCaT cell lines were analyzed in the microarray analyses. Prior to microarray analyses, the integrity of total RNA samples was measured using an Agilent 2100 Bioanalyzer and Agilent RNA 6000 Nano kit (Agilent, Santa Clara, CA, USA). The purity of the RNA was measured using a BioSpec-nano (Shimadzu, Kyoto, Japan). Total RNA samples with RNA integrity number of $\geq 6.0$ (24) and at concentrations of $\geq 130$ $\mathrm{ng} / \mu 1$ were used. Microarray experiments were carried out using GeneChip $^{\mathrm{TM}}$ miRNA 4.1 Array Strip (Applied Biosystems, Thermo Fisher Scientific), FlashTag Biotin HSR RNA Labeling Kits (Applied Biosystems, Thermo Fisher Scientific), GeneChip Hybridization Control Kit (Applied Biosystems, Thermo Fisher Scientific), The GeneAtlas Hybridization, Wash, and Stain Kit for miRNA arrays (Applied Biosystems, Thermo Fisher Scientific) according to the manufacturers' instructions. The Gene Atlas Microarray system (Thermo Fisher Scientific) was used to obtain microarray raw data and the results were analyzed using the Transcriptome Analysis Console (TAC 4.0; Thermo Fisher Scientific). miRs with fold changes in expression levels of $>8$ or $<-8$ and $p$-values of $<0.05$ in all three OSCC cell lines when compared to those in the control HaCaT cells are considered as candidates of new OSCC-associated miRs which control pathogenicity of OSCC. The following miR categories were excluded as candidates of the new OSCC-associated miR: (i) nonhuman miRs; (ii) miRs with low expression level confirmed by miRBase; (iii) miR with scarce literature data; and (iv) miRs which had already been used for clinical trials of miR therapy for cancer (except OSCC).

$R N A$ extraction, real-time reverse transcription $(R T)$ polymerase chain reaction $(P C R)$ of $m i R$. Total RNA was extracted from cell lines using QIAzol Lysis Reagent (Qiagen) and miRNeasy Mini Kit (Qiagen) according to the manufacturer's instructions. The purity of total RNA was measured using BioSpec-nano (Shimadzu). Then, RNA was reverse-transcribed into cDNA using a TaqMan microRNA RT kit (Thermo Fisher Scientific). TaqMan microRNA assays (Applied Biosystems, Thermo Fisher Scientific) using TaqMan universal PCR master mix II, with uracil-N-glycoslyase (UNG) (Applied Biosystems, Thermo Fisher Scientific) were used to assess the expression levels of the candidate miRs detected in our microarray: miR-935 (assay ID: 002178), miR-342-3p (assay ID: 002260), miR-509-3p (assay ID: 002236), miR-3156-5p (assay ID: 244378_mat), and miR-324-5p (assay ID: 001136). The small nuclear RNA 44 (RNU44, assay ID 001094) was used as an internal control to normalize the expression levels of the candidate miRs. Real-time PCRs were performed on the StepOnePlus Real-Time PCR System (Applied Biosystems, Thermo Fisher Scientific). All experiments were performed in triplicate. Expressions were analyzed based on the $\Delta \mathrm{CT}$ value [(CT value of each assay)-(CT value of RNU44)] (25).

Cell transfections. HSC-3-M3 cells were transfected with miR-935 mirVana miRNA mimic (assay ID: MC13067, Invitrogen, Thermo Fisher Scientific) or mirVana miRNA mimic negative control (NC) \#1 (Invitrogen, Thermo Fisher Scientific) at a final concentration of $40 \mathrm{nM}$ using Lipofectamine ${ }^{\circledR}$ RNAiMAX transfection reagent (Invitrogen, Thermo Fisher Scientific) and Opti-MEM (Gibco, Thermo Fisher Scientific) according to the manufacturer's instructions. The transfection efficiency was evaluated by RT-PCR and BLOCK-iT ${ }^{\mathrm{TM}}$ Alexa Fluor $^{\mathrm{TM}}$ Red Fluorescent Control (Invitrogen, Thermo Fisher Scientific).

Cell proliferation assays. HSC-3-M3 cells transfected with miR-935 mimic or miR mimic NC were seeded into 96 -well plates at $1 \times 10^{4}$ cells per well. Cell proliferation was analyzed using CellTiter $96^{\circledR}$ AQueous One Solution Cell Proliferation Assay (MTS assay, Promega, Madison, WI, USA) according to manufacturer's instructions. After four days, the absorbance was measured. Each experiment was performed in triplicate and repeated three times.

Apoptosis assay. HSC-3-M3 cells were seeded into 96-well plate at $1 \times 10^{4}$ cells per well and transfected with miR-935 mimic or miR mimic NC. After $72 \mathrm{~h}$ post transfection, caspase $-3 / 7$ activity was assessed by Caspase-Glo ${ }^{\circledR}$ 3/7 Assay System (Promega) according to the manufacturer's instructions. The assays were performed in triplicate and repeated at least three times.

Cell migration and invasion assays. Cell migration and invasion abilities were assessed using Transwell plate (Corning Incorporated, Life Sciences, Kennebunk, ME, USA). For the invasion assay, matrigel (Corning) diluted in serum-free medium was applied. Transfected cell 
suspension $\left(1 \times 10^{5}\right.$ cells/insert $)$ with serum-free medium was seeded into the upper portion of each chamber. Then, medium containing $10 \%$ NBCS was added to the lower portion of the chambers. After $48 \mathrm{~h}$, the cells on the inside of the Transwell inserts were carefully removed using cotton swabs, and then the cells on the lower surface of the membranes were stained with crystal violet; fluorescence microscopy was used to observe the cells and capture images. Thirty three percent of acetic acid was then added to each insert to elute bound crystal violet. The eluent was transferred to a 96-well plate and the absorbance was measured at $590 \mathrm{~nm}$ using SH-1000Lab (Corona Electric, Ibaraki, Japan) plate reader. Each experiment was performed in triplicate and repeated at least three times.

MiR target prediction and plasmid construction. The online database TargetScan (www.targetscan.org) and miRDB (www.mirdb.org) (26, 27) were used to predict the potential target genes of miR-935, and inositol polyphosphate-4-phosphatase type I A (INPP4A) was predicted as one of the potential target genes of miR-935. To construct a luciferase reporter plasmid pmirGLO-INPP4A 3'UTR wild type (WT), an INPP4A 3'UTR fragment containing a putative miR-935 binding site was inserted into the pmirGLO dual-luciferase miRNA target expression vector (Promega). pmirGLO-INPP4A 3'UTR mutant (MUT) is a derivative of pmirGLO-INPP4A 3'UTR WT, which contains the INPP4A 3'UTR fragment with a mutated miR-935 binding site. These plasmids were constructed by In-Fusion HD cloning kit (Takara Bio USA, CA, USA) according to the manufacturer's instructions using following oligonucleotides: INPP4A 3' UTR WT sense chain 5'-GCTCGCTAGCCTCGACATAATAAATAACTG ACAAGTCGAGTCTAGAGTCG-3', INPP4A 3'UTR WT anti-sense chain 5'-CGACTCTAGACTCGACTTGTCAGTTATTTATTATGTC GAGGCTAGCGAGC-3', INPP4A 3' UTR MUT sense chain 5'G C T C G C T A G C C T C G A C A T A A T A A A T T T G A C ACAAGTCGAGTCTAGAGTCG-3', INPP4A 3' UTR MUT antisense chain 5'-CGACTCTAGACTCGACTTGTGTCAAATTTATTA TGTCGAGGCTAGCGAGC-3'. The DNA sequences for all constructs were confirmed by sequencing analysis.

Luciferase reporter assay. HSC-3-M3 cells were seeded into 96well plates at $1 \times 10^{4}$ cells per well. In total, $200 \mathrm{ng}$ of the reporter plasmids (pmirGLO-INPP4A 3'UTR WT or pmirGLO-INPP4A 3'UTR MUT) and $40 \mathrm{nM}$ of miRs (miR-935 mimic or miR mimic NC) were co-transfected using Lipofectamine ${ }^{\mathrm{TM}} 2000$ Transfection Reagent (Thermo Fisher Scientific), as per manufacturer's instructions. After $24 \mathrm{~h}$ of transfection, the cells were lysed with Glo lysis buffer (Promega), and luciferase activity was measured using the Dual-Glo ${ }^{\circledR}$ Luciferase Assay System (Promega). The values obtained for firefly luciferase were normalized to those of Renilla luciferase. All experiments were performed in triplicate and repeated at least three times.

Real-time RT-PCR for mRNA. Total RNA from HSC-3-M3 cells transfected with miR-935 mimic or mimic NC were extracted using QIAzol Lysis Reagent and miRNeasy Mini Kit. Purity of total RNA was measured using BioSpec-nano. RT was carried out using a HighCapacity RNA-to-cDNA ${ }^{\mathrm{TM}}$ Kit (Thermo Fisher Scientific). The following primers were used: INPP4A (assay ID: Hs01047092_m1) and GAPDH (assay ID: Hs02786624_g1). The expression of INPP4A mRNA levels was assessed using TaqMan ${ }^{\mathrm{TM}}$ Gene Expression Assay with TaqMan universal PCR master mix II, with UNG (Applied Biosystems, Thermo Fisher Scientific) and the StepOnePlus Real-
Time PCR System. All experiments were performed in triplicate and repeated at least three times. GAPDH was used as an internal control. The mRNA expression levels were analyzed using the comparative threshold cycle method $\left(2^{-\Delta \Delta C T}\right)(25)$.

Western blotting. Total protein from HSC-3-M3 cells was extracted using RIPA Buffer (ab156034; Abcam, Cambridge, UK) supplemented with Protease Inhibitor Cocktail for Use with Mammalian Cell and Tissue Extracts (25955-24; Nacalai Tesque, Kyoto, Japan). After removing cell debris by centrifugation, the clear cell lysates were boiled with Sample Buffer Solution with Reducing Reagent (6x) for SDS-PAGE (09499-14; Nacalai Tesque). Ten to twenty $\mu \mathrm{g}$ of protein samples were separated by SDS-PAGE gels and then transferred to PVDF membranes (Merck KGaA, Darmstadt, Germany). After blocking with Blocking One (0395366; Nacalai Tesque), the membranes were incubated with primary antibodies overnight at $4{ }^{\circ} \mathrm{C}$, followed by incubation with anti-mouse or anti-rabbit IgG conjugated with horseradish-peroxidase (HRP) at room temperature for $1 \mathrm{~h}$. Chemi-Lumi One Ultra (11644-24; Nacalai Tesque) or SuperSignal ${ }^{\mathrm{TM}}$ West Dura Extended Duration Substrate (Thermo Fisher Scientific) was used for signal detection. The chemiluminescent signals were detected using ImageQuant LAS 4000 Mini (Cytiva, Tokyo, Japan). Primary antibodies used in this study were as follows: INPP4A (1:1,000, ab109622, Abcam), $\beta$-actin $(1: 10,000, A 1978$, Sigma-Aldrich). To verify the specificity of anti-INPP4A antibody, two siRNAs designed to target INPP4A (assay ID: s7450 and s7451, Invitrogen, Thermo Fisher Scientific) were introduced into HSC-3-M3 cells. Blots were analyzed using ImageJ software (National Institutes of Health, Bethesda, MD, USA) (28). Each experiment was performed independently at least three times, unless otherwise stated.

Statistical analysis. The Transcriptome Analysis Console 4.0 was used for array analysis. The association of the $\Delta \mathrm{CT}$ value between human OSCC tissues and paired normal tissues was confirmed using the paired $t$-test. A $p$-value of $<0.05$ was considered indicative of statistical significance. For remaining analyses, Student $t$-test was used. All statistical analyses were performed using JMP ${ }^{\circledR}$ Pro 15 (SAS Institute Inc., Cary, NC, USA).

\section{Results}

MiR-935 and miR-509-3p are down-regulated in human OSCC tissue and OSCC cell lines. In order to find miRs whose expression levels are altered in OSCC cells, we performed a microarray analysis to compare the expression levels of miRs among the three OSCC cell lines and HaCaT cells. We identified four miRs that were up-regulated more than eight-fold and 14 miRs that were down-regulated by less than minus eight-fold in OSCC cell lines compared to HaCaT cells (Tables I, II and Figure 1) $(29,30)$.

In this study, the following categories of miR were excluded from the candidate of the new OSCC-associated miR: (i) nonhuman miRs; (ii) miRs with low expression level confirmed by miRBase; (iii) miR with scarce literature data; and (iv) miRs which had already been used for clinical trials of miR therapy for cancer (except OSCC). Of the up-regulated miRs (Table I), miR-664b-3p was excluded because of its inherent low 
Table I. miR with up-regulated expression in OSCC cell lines.

\begin{tabular}{|c|c|c|c|c|c|}
\hline miR name & Condition F-Test & Condition FDR F-Test & HSC-3-M3 fold change & HSC-3 fold change & SAS fold change \\
\hline hsa-miR-324-5p & $8.5 \mathrm{E}-03$ & 0.0615 & 9.07 & 8 & 16.13 \\
\hline hsa-miR-342-3p & 4.67E-06 & 0.0003 & 26.3 & 28.94 & 29.97 \\
\hline hsa-miR-664b-3p & $2.65 \mathrm{E}-05$ & 0.001 & 21.44 & 63.28 & 14.39 \\
\hline hsa-miR-3156-5p & $6.00 \mathrm{E}-06$ & 0.0003 & 10.5 & 69.24 & 9.69 \\
\hline
\end{tabular}

$\mathrm{HaCaT}$ cells were used as normalization control. FDR, False discovery rate; miR, microRNA; OSCC, oral squamous cell carcinoma.

Table II. miR with down-regulated expression in OSCC cell lines.

\begin{tabular}{|c|c|c|c|c|c|}
\hline miR name & Condition F-Test & Condition FDR F-Test & HSC-3-M3 fold change & HSC-3 fold change & SAS fold change \\
\hline hsa-miR-34a-5p & 8.83E-06 & 0.0004 & -28.62 & -47.07 & -12.1 \\
\hline hsa-miR-145-5p & $6.6 \mathrm{E}-03$ & 0.0513 & -10.56 & -11.89 & -12.3 \\
\hline hsa-miR-184 & $4.00 \mathrm{E}-09$ & $1.86 \mathrm{E}-06$ & -30.72 & -31.74 & -10.6 \\
\hline hsa-miR-192-5p & $1.08 \mathrm{E}-06$ & 0.0001 & -10.66 & -9.94 & -16.49 \\
\hline hsa-miR-362-5p & $1.54 \mathrm{E}-05$ & 0.0007 & -55.85 & -66.21 & -11.55 \\
\hline hsa-miR-365b-5p & $3.06 \mathrm{E}-09$ & $1.56 \mathrm{E}-06$ & -24.19 & -10.61 & -17.91 \\
\hline hsa-miR-500a-3p & $3.89 \mathrm{E}-12$ & $1.16 \mathrm{E}-08$ & -107.31 & -100.11 & -10.87 \\
\hline hsa-miR-501-3p & $9.76 \mathrm{E}-09$ & $3.41 \mathrm{E}-06$ & -57.93 & -55.22 & -9.45 \\
\hline hsa-miR-509-3p & $7.27 \mathrm{E}-12$ & $1.16 \mathrm{E}-08$ & -17.43 & -18.94 & -19.6 \\
\hline hsa-miR-532-3p & $5.15 \mathrm{E}-09$ & $2.13 \mathrm{E}-06$ & -53.73 & -48.21 & -11.22 \\
\hline hsa-miR-935 & $1.86 \mathrm{E}-10$ & 1.23E-07 & -12.69 & -12.19 & -14.1 \\
\hline hsa-miR-6746-5p & 2.08E-07 & $3.73 \mathrm{E}-05$ & -17.36 & -19.41 & -10.68 \\
\hline hsa-miR-6762-5p & 5.07E-11 & 4.80E- 08 & -63.48 & -72.17 & -38.55 \\
\hline hsa-miR-6801-5p & $6.09 \mathrm{E}-11$ & $5.05 E-08$ & -128.34 & -100.34 & -74.53 \\
\hline
\end{tabular}

Bold values depict potential study candidate miRs with fold changes in the expression level of $<-12$ in all three OSCC lines. HaCaT cells were used as normalization control. FDR, False discovery rate; miR, microRNA; OSCC, oral squamous cell carcinoma.

expression according to miRBase. As several miRs were downregulated, less than minus eight-fold changes in OSCC cell lines were observed, and the miRs with less than -12-fold changes in all three OSCC lines were chosen as potential study candidates (bolded in Table II). Of those, miR-6762-5p and miR-6801-5p were excluded as no function was reported. Further, miR-34a-5p was also excluded because miR therapy (as MRX34 for another cancer) has been studied and withdrawn due to strong side-effects $(31,32)$. To validate our microarray results, the expression levels of the five miR candidates, miR-324-5p, miR-342-3p, miR-509-3p, miR-935, and miR-3156-5p, were assessed by quantitative RT-PCR. In experiments with 20 OSCC tissue samples and matched adjacent normal tissues, both miR-935 and miR-509-3p showed significantly lower expression in OSCC tissues than its expression in normal tissues, consistent with the microarray results ( $p<0.05$ : Figure $2 \mathrm{~A}$ and $\mathrm{B})$. The expression levels of the remaining three miRs in cancer tissues were inconsistent with the array data [miR-324-5p $\quad(p=0.3424), \quad$ miR-342-3p $(p=0.4291)$, and miR-3156-5p $(p=0.0005$; however, data indicated that cancer had significantly lower expression than normal tissue)] (Figure 2C-E). Since the aim of this study was to find new candidate(s) of OSCC-regulating miR, miR-509$3 p$ was omitted from this study as has been reported previously (33). Therefore, we chose miR-935 for further analyses.

Overexpression of miR-935 decreases cell proliferation, migration, and invasion and increases apoptosis of OSCC. The biological function of miR-935 in OSCC was examined. The overexpression of miR-935 in HSC-3-M3 cells decreased cell proliferation, as assessed by the MTS assay (Figure 3A). Transwell assays showed decreased migration and invasion of cells expressing miR-935 compared to those expressing miR mimic NC (Figure 3B and C). Furthermore, overexpression of miR-935 in the OSCC cell increased caspase -3 and -7 activity, suggesting that miR-935 promotes apoptosis (Figure 3D).

INPP4A as a potential target of $m i R-935$. Our results indicate that miR-935 may function as a tumor suppressor in OSCC cells. To understand the mechanisms underlying miR-935 in OSCC suppression, we aimed to identify the target genes of 


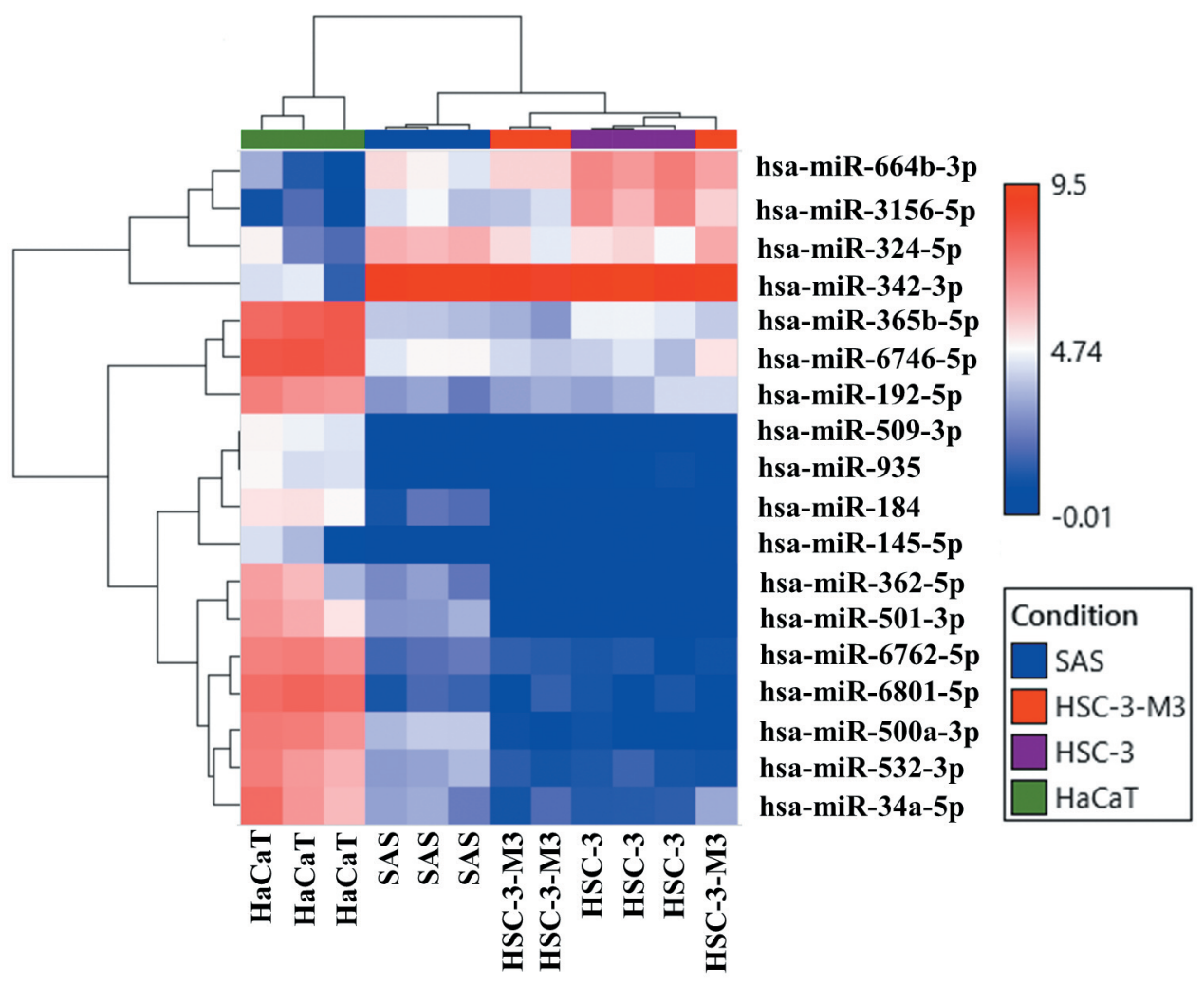

Figure 1. miR-935 was down-regulated in OSCC cell lines. The heat map shows 18 differentially regulated miRs between the three OSCC cell lines and the non-cancer cell line (>8-fold or <-8-fold differences). miR, microRNA; OSCC, oral squamous cell carcinoma.

miR-935. Using the online database TargetScan (www.targets can.org), the position of 2530-2536 in the 3'UTR of INPP4A was identified as a potential target sequence of miR-935 (Figure 4A). We cloned the genomic DNA flanking this region and constructed a reporter plasmid pmirGLO-INPP4A 3'UTR WT in which the firefly luciferase gene expression is regulated by the 3'UTR of INPP4A. Co-transfection of miR935 with pmirGLO-INPP4A 3'UTR WT, but not with pmirGLO-INPP4A 3'UTR MUT harboring a mutation at miR-935-complementary nucleotides, resulted in higher luciferase activity than miR mimic NC in HSC-3-M3 cells, indicating that miR-935 positively regulates the gene expression through the 3'UTR of INPP4A (Figure 4B). Finally, we examined the expression levels of endogenous INPP4A in HSC-3-M3 cells. Quantitative RT-PCR analysis revealed that the amount of INPP4A mRNA was increased in cells transfected with miR-935 mimic compared to those transfected with miR mimic NC (Figure 4C). The effect of miR-935 mimic on the expression of endogenous INPP4A was also confirmed at the protein level as assessed using western blotting (Figure 4D and E). These results strongly suggest that miR-935 positively regulates the expression of INPP4A gene in OSCC.

\section{Discussion}

This is the first report on the comparison of miR expression with microarray using multiple OSCC cell lines (HSC-3, HSC-3-M3, and SAS). Among all available OSCC cell lines, we selected these three cell lines based on the following criteria: (i) those used for in vitro $\mathrm{miR}$ mimic/inhibitor (miRvana) study $(34,35)$ and (ii) those studied in the orthotopic tongue tumor model of OSCC (36-38). HSC-3M3 was chosen as an in vitro model because mouse model experiments have been reported $(38,39)$, and our other preliminary in vivo analysis had confirmed that HSC-3-M3 has high potential of lymph node metastasis (data not shown). In this study, we found that miR-935 expression is significantly reduced in all three OSCC cell lines as well as in OSCC patient tissues. We also found that overexpression of miR-935 inhibits cancer cell proliferation, invasion and migration, and induces caspase-3/7 activation. Furthermore, this is the first study to show that INPP4A is expressed in head and neck cancers and its expression is positively regulated by miR-935. Thus, these results suggest that miR935 may function as a tumor suppressor that inhibits OSCC progression, possibly by targeting INPP4A. 

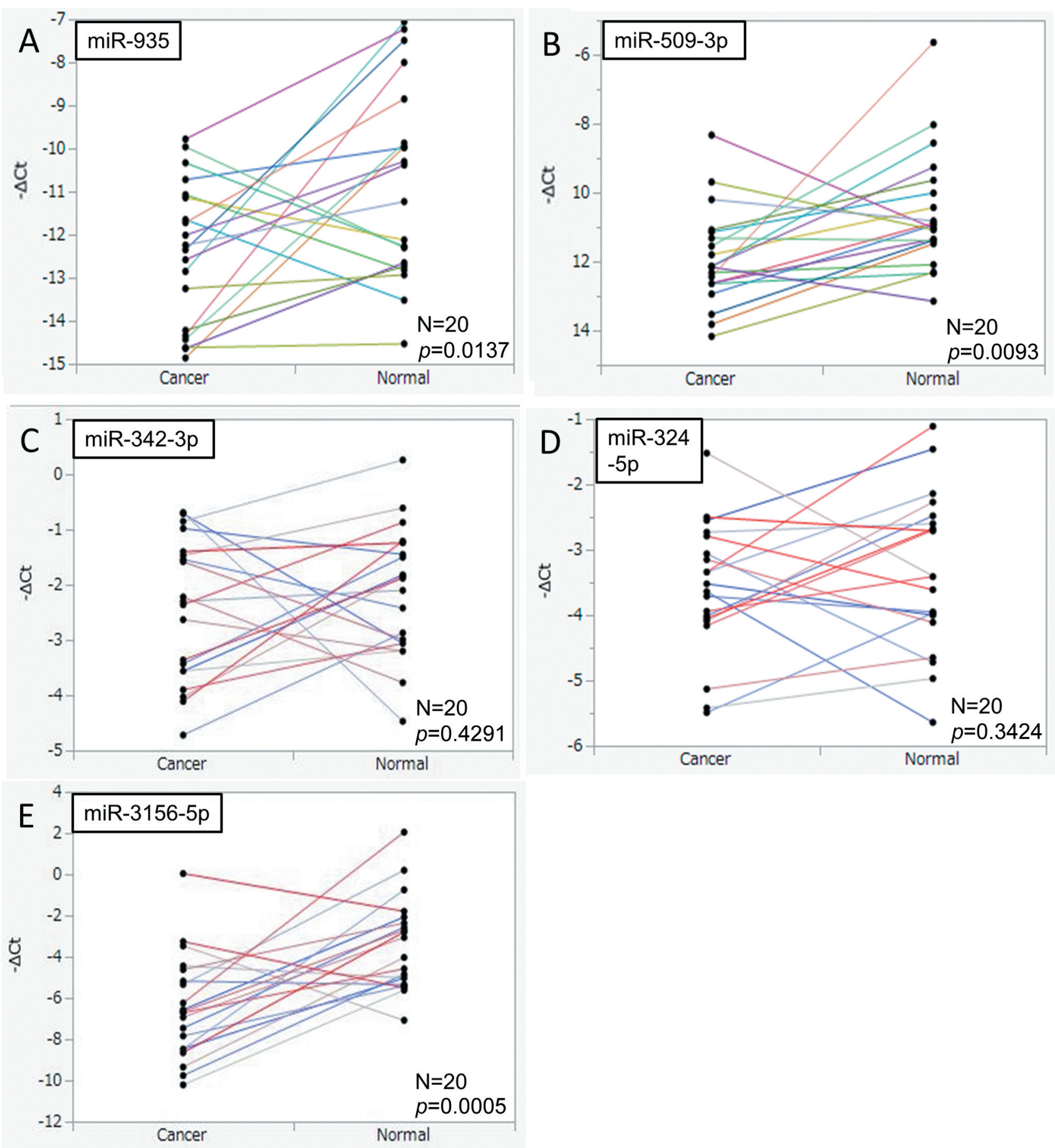

Figure 2. $\triangle C T$ value of five miR expressions in OSCC tissues and paired adjacent normal tissues by real-time RT-PCR assay. (A) miR-935. (B) miR509-3p. (C) miR-342-3p. (D) miR-324-5p. (E) miR-3156-5p. miR, microRNA. OSCC, Oral squamous cell carcinoma.

We propose that miR-935 can be a new therapeutic target for OSCC. miR-935 is related with various types of human cancers. However, contradictory results have been reported regarding the function of miR-935 (as a tumor suppressing $\mathrm{miR}$ or tumor promoting onco-miR) depending on the type and site of cancer $(40,41)$. In fact, miR-935 is a tumor suppressor in non-small cell lung cancer that inhibits E2F7 (40), in gastric signet ring cell carcinoma that inhibits Notch1 (42), and in osteosarcoma that inhibits HMGB1 (43). Moreover, underexpression of miR-935 has also been 
A

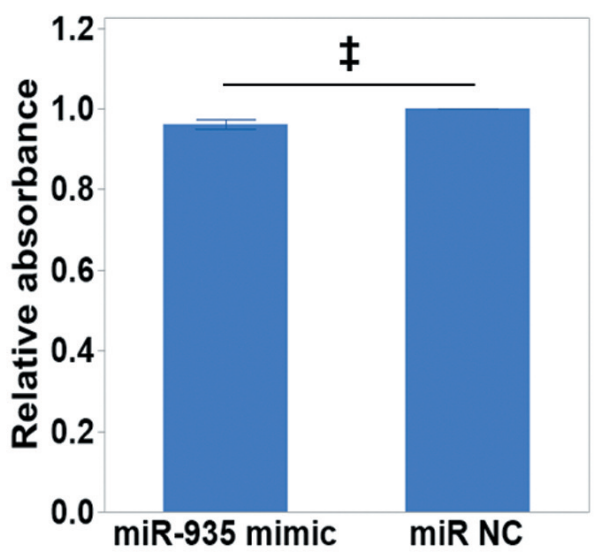

\section{B: Migration}
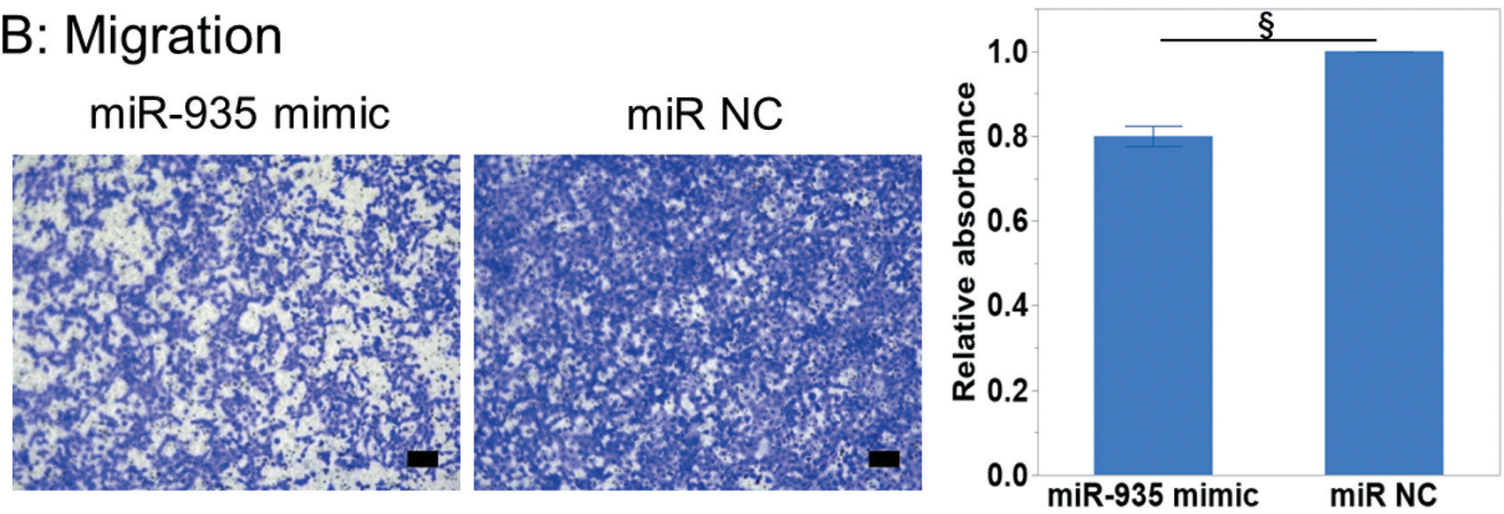

\section{C: Invasion}
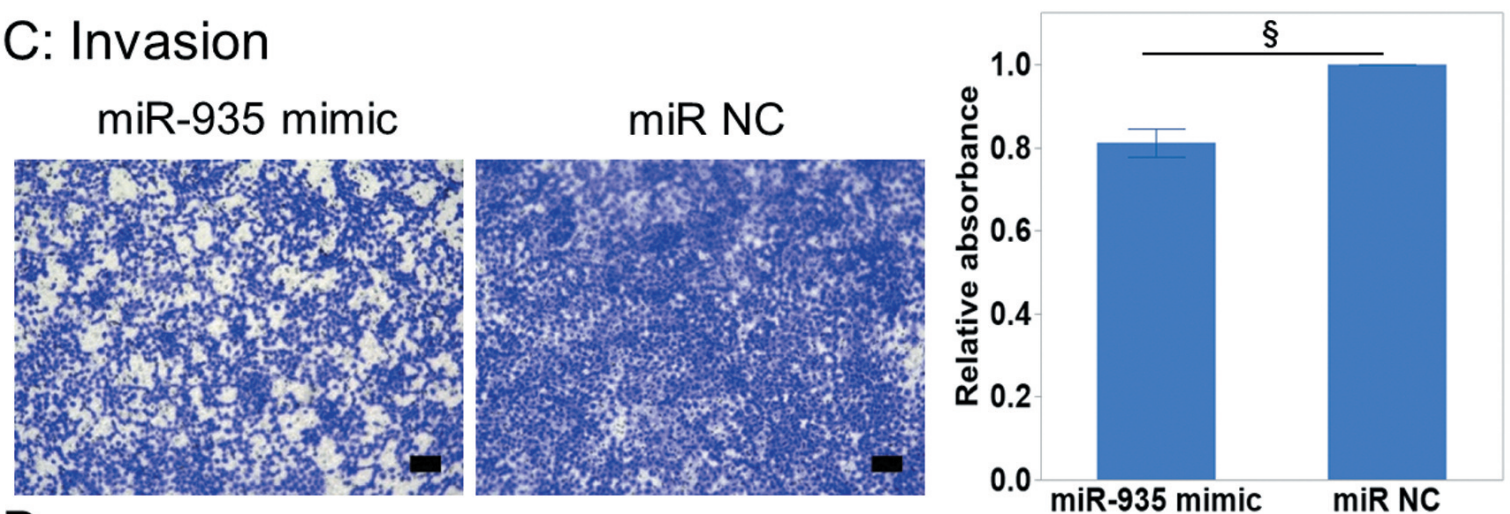

\section{D}

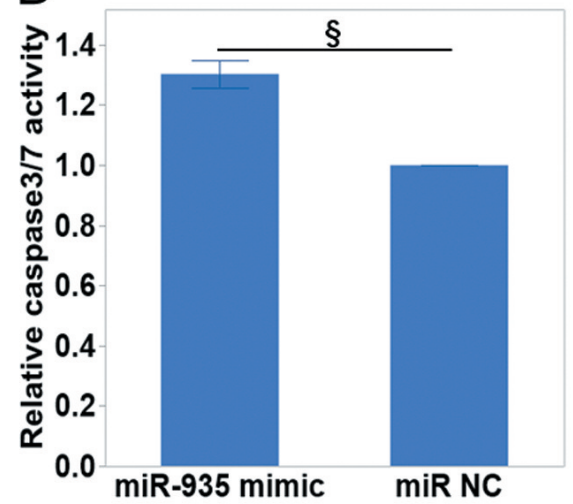

Figure 3. Overexpression of miR-935 inhibits HSC-3-M3 cell proliferation, migration, and invasion and promotes cell apoptosis. (A) MTS assay to assess the proliferation of HSC-3-M3 cells 4 days after transfection with miR-935 mimic or miR mimic $N C(\hbar p<0.005)$. $(B, C)$ Transwell migration and invasion assays of HSC-3-M3 cells transfected with miR-935 mimic or miR mimic NC (B: migration assay; $C$ : invasion assay. Left panels: representative images of crystal violet staining. Original magnification, $10 \times$. Scale bar: $100 \mu \mathrm{m}$. Right panels: relative absorbance of miR-935 mimic and miR mimic NC. $\left.{ }^{\S} p<0.001\right)$. (D) miR935 mimic increases caspase -3 and -7 activities as compared to those in miR mimic $N C\left(\xi_{p}<0.001\right)$. The error bars represent the standard error. miR, microRNA. NC, Mimic negative control. 

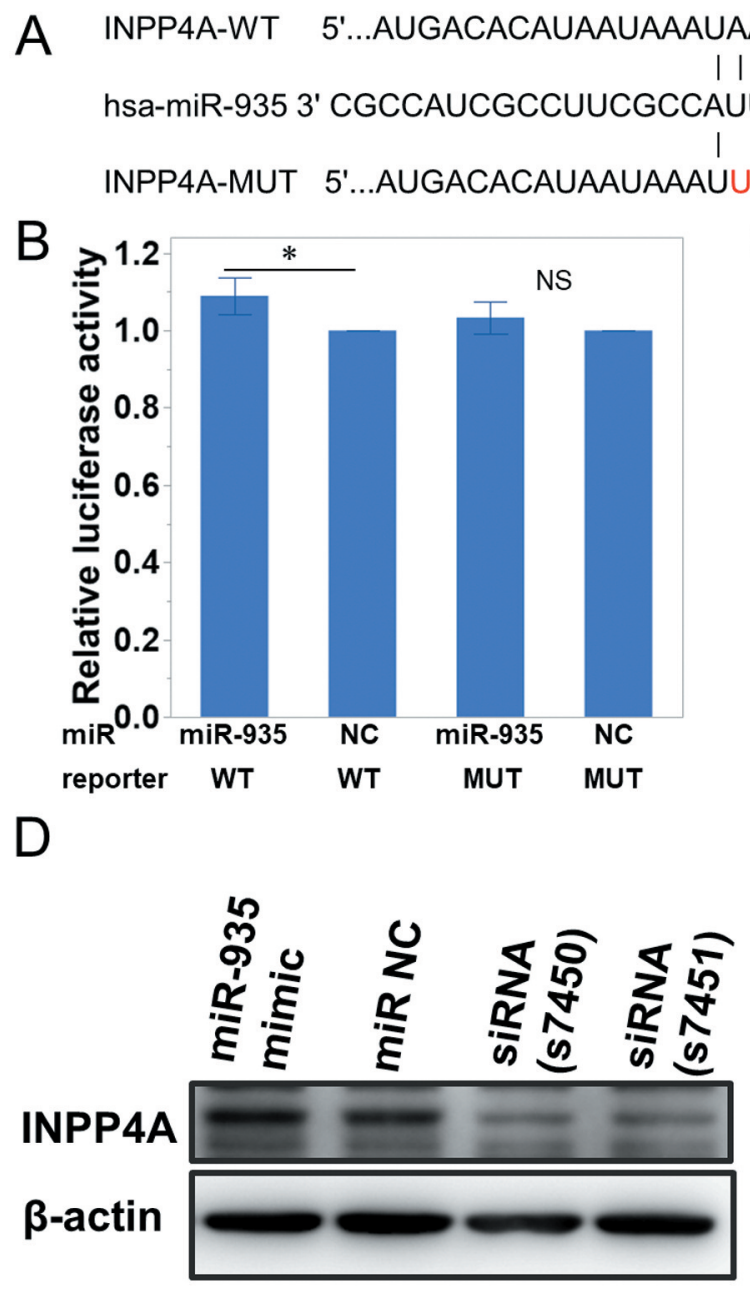

| | | | |

AUUGACC

I

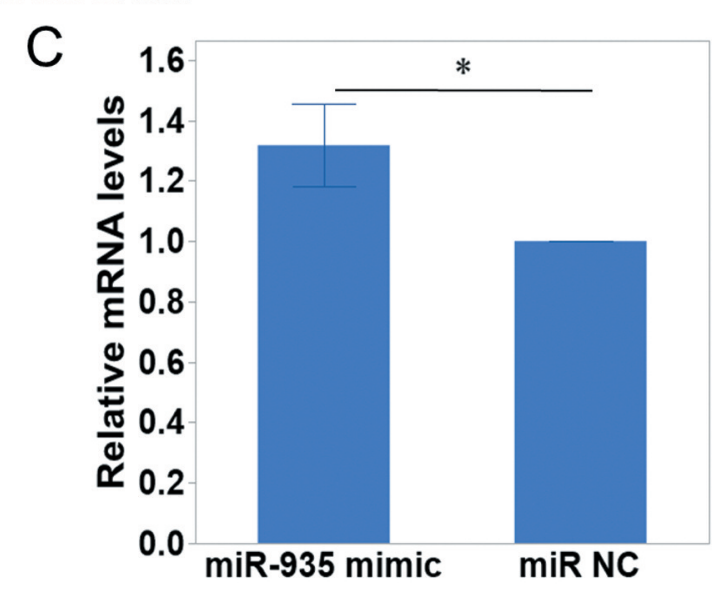

E

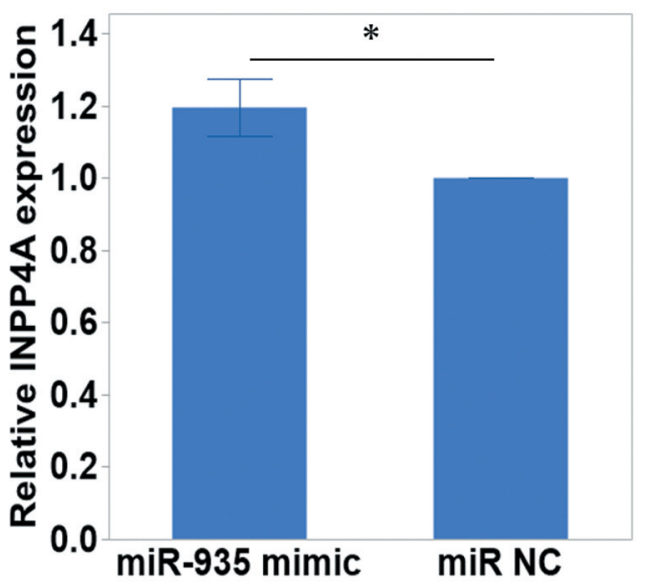

Figure 4. INPP4A is a target gene of miR-935. (A) The alignment of miR-935 with 3'UTR of INPP4A mRNA. The sequences of predicted target site of miR-935 in the INPP4A 3'UTR WT and positions of five mutated nucleotides in the INPP4A 3'UTR-MUT are illustrated. The mutated nucleotides are shown in red. (B) Effect of miR-935 on 3'UTR of INPP4A. HSC-3-M3 cells co-transfected with pmirGLO-INPP4A 3'UTR WT (WT) or pmiRGLO-INPP4A 3'UTR MUT (MUT) reporter plasmids and miR-935 mimic (miR-935) or control mimic miR (NC). Luciferase activities were determined and normalized to levels of Renilla luciferase activity. Results are expressed as the relative luciferase activity compared to $N C\left({ }^{*} p<0.05 ; N S\right.$, not significant). (C) Effect of miR-935 on expression of INPP4A mRNA. HSC-3-M3 cells were transfected with miR-935 mimic or control mimic miR (NC). The amount of INPP4A mRNA was quantified by RT-qPCR analysis $\left({ }^{*} p<0.05\right)$. (D) Effect of miR-935 on endogenous INPP4A protein expression. HSC-3-M3 cells were transfected with miR-935 mimic, control mimic miR (NC) or siRNAs against INPP4A. Total cell lysates were analyzed by SDS-PAGE followed by western blotting using anti-INPP4A antibody (upper panel). $\beta$-actin was used as loading control (lower panel). INPP4A knockdown by siRNAs was confirmed in two independent experiments. (E) Quantification of the results shown in (D). The band intensity was quantified by the ImageJ software and was normalized to the corresponding $\beta$-actin value $\left({ }^{*} p<0.05\right)$. The error bars represent the standard error. miR, microRNA. NC, Mimic negative control.

reported in glioblastoma (44), medulloblastoma (45), uveal melanoma with monosomy-3 (46), 5-FU resistant variants of esophagus SCC (47), non-small cell lung cancer (48), invasive breast cancer cells stably transfected with KLK5 (49), an anoikis resistant variant of the luminal A type breast cancer cells (50), pancreatic cancer (51), bladder cancer (52), colon cancer cell lines with higher potential of metastasis
(53), and ovarian cancer (array data of the Gene Expression Omnibus) (54).

Conversely, miR-935 is reported as an onco-miR in gastric cancer that inhibits SOX7 (55), in non-small cell lung cancer that inhibits IL-27 (41), in non-small-cell lung cancer that inhibits SOX7 (56), in hepatocellular carcinoma that inhibits SOX7 and activates c-Myc and cyclin D1 (57), in pancreatic 
carcinoma that inhibits INPP4A and possibly p27 (58), and in colorectal cancer that targets INPP4A (59). In addition, overexpression of miR-935 has been reported in stathmindepleted neuroblastoma (60), Helicobacter pylori-positive gastric cancer (using Gene Expression Omnibus database) (61), stage-I endometrioid endometrial cancer (62), bladder cancer (63), and chronic hepatitis B that progressed to cirrhosis/hepatocellular carcinoma (64). In high-grade precancerous cervical lesions, methylation levels of miR-935 were remarkably high (65). miR-935 has been also identified as one of the novel candidate miRs using human cervical cancer cell lines and normal cervical samples (66). Although various studies indicate that miR-935 could be an attractive target for anticancer therapy, one must consider whether to stimulate or inhibit the function of miR-935 for the treatment because of its context-dependent effects.

Using the TargetScan, miRDB, and luciferase reporter assay, we identified INPP4A as a target gene of miR-935. INPP4A is a 107-kDa lipid phosphatase (67). INPP4A can dephosphorylate $\mathrm{PI}(3,4) \mathrm{P} 2$, convert $\mathrm{PI}(3,4) \mathrm{P} 2$ to $\mathrm{PI}(3) \mathrm{P}$, and negatively regulate PI3K-Akt signaling $(68,69)$. The function and metabolic pathway of INPP4A are well known in non-cancerous diseases such as asthma and intractable epilepsy $(68,70)$. However, the role of INPP4A in cancer progression has been elusive despite its relationship with tumor-related pathways such as PI3K-Akt, PTEN, and JAK2/STAT3 pathways (58, 68, 71-73). INPP4A is able to block $\mathrm{PI}(3,4) \mathrm{P} 2$, which is related with cancer malignancy (e.g., invasion and metastasis) $(68,74)$. Recently, Chaudhuri et al. reported that INPP4A acts as a tumor suppressor, and the nuclear translocation of INPP4A might be a checkpoint to regulate cancer cell cycle, proliferation, and might promote apoptosis (75). INPP4A has attracted attention in cancer research because of the strong evidence regarding its tumor suppressor activity (74). INPP4A-related miRs are also reported in the field of cancer (72-75).

Previous studies have reported that miR-935 promotes tumor cell growth by inhibiting INPP4A $(58,59)$; however, we clearly demonstrated that miR-935 enhances INPP4A expression and suppresses cell growth in HSC-3-M3 cells. In fact, some studies have reported that miR actually enhances the expression of target genes (76-83). Thus, it is likely that the molecular mechanisms underlying the expression of miR-935 and the regulation of INPP4A by miR-935 are different in OSCC and other cancer cells. Further studies are required to understand the contextdependent regulatory mechanisms of miR-935/INPP4A axis. Moreover, given the opposite effects of miR-935 depending on the cell types, careful consideration is required to develop a new drug targeting miR-935/INPP4A axis.

To date, many miRs are reported to be involved in OSCC malignancy. For example, it was reported that miR-155-5p might contribute to epithelial-mesenchymal transition (EMT) which enhances OSCC progression (84). OSCC has many steps, such as carcinogenesis, progression, invasion, EMT and metastasis (85). PI3K/Akt pathway is known to play important roles in controlling all these steps (86-89). The potential targets of miR-155-5p includes PTEN (90) and SHIP1 (91), both of which negatively regulate PI3K/Akt signaling pathway $(90,92)$. Given that miR-935/INPP4A axis could also regulate PI3K/Akt pathway, it is conceivable that targeting both miR-935 and miR-155-5p may lead to better outcomes in OSCC treatment.

\section{Conclusion}

We found that miR-935 has low expression in OSCC cell lines and OSCC patient specimens. Functional analysis suggested that miR-935 positively regulate the expression of INPP4A and may suppress the malignancy of OSCC. Therefore, miR-935 may act as a tumor suppressor in OSCC and could serve as a potential therapeutic target for OSCC.

\section{Conflicts of Interest}

The Authors declare no conflicts of interest.

\section{Authors' Contributions}

NM, MU, TM, FH, AA and GT acquired the data. NM, MU, TM, AA and GT substantially contributed to the concept and design of the study. NM and TM performed the literature review and had a major role in writing the manuscript. MU, FH, GM and GT revised the manuscript. HM, KN, TN, AM, TG, HN and GM interpreted the data and contributed advice for the manuscript. All Authors have read and agreed to the final manuscript.

\section{Acknowledgements}

The Authors would like to thank all staff of the Center for Research Advancement and Collaboration, and the Center for Strategic Research Project of the University of the Ryukyus for their technical supports. We are grateful to Dr. N.E. Fusenig (German Cancer Research Center (DKFZ), Heidelberg, Germany) for providing us with the HaCaT cell line. The Authors would like to also thank Ace Statistics Support Co, Ltd. for their help with the statistical analyses of the data.

\section{References}

1 Bray F, Ferlay J, Soerjomataram I, Siegel RL, Torre LA and Jemal A: Global cancer statistics 2018: GLOBOCAN estimates of incidence and mortality worldwide for 36 cancers in 185 countries. CA Cancer J Clin 68(6): 394-424, 2018. PMID: 30207593. DOI: $10.3322 /$ caac. 21492

2 Brierley JD, Gospodarowicz M and Wittekind C (eds): Lip and Oral Cavity. In: TNM Classification of Malignant Tumours. 8th edition. Wiley Blackwell, New York, NY, pp. 18-21, 2016.

3 Siegel RL, Miller KD and Jemal A: Cancer statistics, 2019. CA Cancer J Clin 69(1): 7-34, 2019. PMID: 30620402. DOI: $10.3322 /$ caac. 21551 
4 Boring CC, Squires TS and Tong T: Cancer statistics, 1993. CA Cancer J Clin 43(1): 7-26, 1993. PMID: 8422609. DOI: 10.3322/canjclin.43.1.7

5 Chi AC, Day TA and Neville BW: Oral cavity and oropharyngeal squamous cell carcinoma-an update. CA Cancer J Clin 65(5): 401-421, 2015. PMID: 26215712. DOI: 10.3322/caac.21293

6 Lydiatt WM, Patel SG, O'Sullivan B, Brandwein MS, Ridge JA, Migliacci JC, Loomis AM and Shah JP.: Head and Neck cancersmajor changes in the American Joint Committee on cancer eighth edition cancer staging manual. CA Cancer J Clin 67(2): 122-137, 2017. PMID: 28128848. DOI: 10.3322/caac.21389

7 Schwam ZG and Judson BL: Improved prognosis for patients with oral cavity squamous cell carcinoma: Analysis of the National Cancer Database 1998-2006. Oral Oncol 52: 45-51, 2016. PMID: 26553389. DOI: 10.1016/j.oraloncology.2015.10.012

8 Biddle A, Gammon L, Liang X, Costea DE and Mackenzie IC: Phenotypic plasticity determines cancer stem cell therapeutic resistance in oral squamous cell carcinoma. EBioMedicine 4: 138145, 2016. PMID: 26981578. DOI: 10.1016/j.ebiom.2016.01.007

9 Jia $\mathrm{L}$, Wang $\mathrm{J}, \mathrm{Wu} \mathrm{T}, \mathrm{Wu} \mathrm{J}$, Ling $\mathrm{J}$ and Cheng B: In vitro and in vivo antitumor effects of chloroquine on oral squamous cell carcinoma. Mol Med Rep 16(5): 5779-5786, 2017. PMID: 28849182. DOI: $10.3892 / \mathrm{mmr} .2017 .7342$

10 Zhong LP, Zhang CP, Ren GX, Guo W, William WN Jr, Hong CS, Sun J, Zhu HG, Tu WY, Li J, Cai YL, Yin QM, Wang LZ, Wang ZH, Hu YJ, Ji T, Yang WJ, Ye WM, Li J, He Y, Wang YA, Xu LQ, Zhuang Z, Lee JJ, Myers JN and Zhang ZY: Long-term results of a randomized phase III trial of TPF induction chemotherapy followed by surgery and radiation in locally advanced oral squamous cell carcinoma. Oncotarget 6(21): 18707-18714, 2015. PMID: 26124084. DOI: 10.18632/oncotarget.4531

11 Siriwardena SBSM, Tsunematsu T, Qi G, Ishimaru N and Kudo Y: Invasion-related factors as potential diagnostic and therapeutic targets in oral squamous cell carcinoma-a review. Int J Mol Sci 19(5): 1462, 2018. PMID: 29758011. DOI: 10.3390/ijms 19051462

12 Sakha S, Muramatsu T, Ueda K and Inazawa J: Exosomal microRNA miR-1246 induces cell motility and invasion through the regulation of DENND2D in oral squamous cell carcinoma. Sci Rep 6: 38750, 2016. PMID: 27929118. DOI: 10.1038/srep38750

$13 \mathrm{Yu} \mathrm{X}$ and Li Z: MicroRNA expression and its implications for diagnosis and therapy of tongue squamous cell carcinoma. J Cell Mol Med 20(1): 10-16, 2016. PMID: 26498914. DOI: $10.1111 / \mathrm{jcmm} .12650$

14 Jiang L, Liu X, Kolokythas A, Yu J, Wang A, Heidbreder CE, Shi F and Zhou X: Downregulation of the Rho GTPase signaling pathway is involved in the microRNA-138-mediated inhibition of cell migration and invasion in tongue squamous cell carcinoma. Int $\mathrm{J}$ Cancer 127(3): 505-512, 2010. PMID: 20232393. DOI: $10.1002 / \mathrm{ijc} .25320$

15 Rather MI, Nagashri MN, Swamy SS, Gopinath KS and Kumar A: Oncogenic microRNA-155 down-regulates tumor suppressor CDC73 and promotes oral squamous cell carcinoma cell proliferation: implications for cancer therapeutics. J Biol Chem 288(1): 608-618, 2013. PMID: 23166327. DOI: 10.1074/ jbc.M112.425736

16 Zeng RC, Zhang W, Yan XQ, Ye ZQ, Chen ED, Huang DP, Zhang $\mathrm{XH}$ and Huang GL: Down-regulation of miRNA-30a in human plasma is a novel marker for breast cancer. Med Oncol 30(1): 477, 2013. PMID: 23389917. DOI: 10.1007/s12032-013-0477-z
17 Calin GA, Dumitru CD, Shimizu M, Bichi R, Zupo S, Noch E, Aldler H, Rattan S, Keating M, Rai K, Rassenti L, Kipps T, Negrini M, Bullrich F and Croce CM: Frequent deletions and down-regulation of micro-RNA genes miR15 and miR16 at 13 q14 in chronic lymphocytic leukemia. Proc Natl Acad Sci USA 99(24): 15524-15529, 2002. PMID: 12434020. DOI: $10.1073 /$ pnas. 242606799

18 Lin S and Gregory RI: MicroRNA biogenesis pathways in cancer. Nat Rev Cancer 15(6): 321-333, 2015. PMID: 25998712. DOI: $10.1038 / \mathrm{nrc} 3932$

19 Kozomara A, Birgaoanu M and Griffiths-Jones S: miRBase: from microRNA sequences to function. Nucleic Acids Res 47(D1): D155-D162, 2019. PMID: 30423142. DOI: 10.1093/nar/gky1141

20 Wang YJ, Zhang ZF, Fan SH, Zhuang J, Shan Q, Han XR, Wen $\mathrm{X}$, Li MQ, Hu B, Sun CH, Qiao B, Tao Q, Wu DM, Lu J and Zheng YL: MicroRNA-433 inhibits oral squamous cell carcinoma cells by targeting FAK. Oncotarget 8(59): 100227-100241, 2017. PMID: 29245973. DOI: 10.18632/oncotarget.22151

21 Nagai H, Hasegawa S, Uchida F, Terabe T, Ishibashi Kanno N, Kato K, Yamagata K, Sakai S, Kawashiri S, Sato H, Yanagawa T and Bukawa H: MicroRNA-205-5p suppresses the invasiveness of oral squamous cell carcinoma by inhibiting TIMP-2 expression. Int J Oncol 52(3): 841-850, 2018. PMID: 29393341. DOI: 10.3892/ijo.2018.4260

22 Wu B, Lei D, Wang L, Yang X, Jia S, Yang Z, Shan C, Yang X, Zhang $\mathrm{C}$ and Lu B: MiRNA-101 inhibits oral squamous-cell carcinoma growth and metastasis by targeting zinc finger E-box binding homeobox 1. Am J Cancer Res 6(6): 1396-1407, 2016. PMID: 27429852

23 Boukamp P, Petrussevska RT, Breitkreutz D, Hornung J, Markham A and Fusenig NE: Normal keratinization in a spontaneously immortalized aneuploid human keratinocyte cell line. J Cell Biol 106(3): 761-771, 1988. PMID: 2450098. DOI: $10.1083 /$ jcb.106.3.761

24 Mao L, Li J, Chen WX, Cai YQ, Yu DD, Zhong SL, Zhao JH, Zhou JW and Tang JH: Exosomes decrease sensitivity of breast cancer cells to adriamycin by delivering microRNAs. Tumour Biol 37(4): 5247-5256, 2016. PMID: 26555545. DOI: $10.1007 / \mathrm{s} 13277-015-4402-2$

25 Livak KJ and Schmittgen TD: Analysis of relative gene expression data using real-time quantitative PCR and the 2(Delta Delta C(T)) Method. Methods 25(4): 402-408, 2001. PMID: 11846609. DOI: 10.1006/meth.2001.1262

26 Agarwal V, Bell GW, Nam JW and Bartel DP: Predicting effective microRNA target sites in mammalian mRNAs. Elife 4: e05005, 2015. PMID: 26267216. DOI: 10.7554/eLife.05005

27 Chen Y and Wang X: miRDB: an online database for prediction of functional microRNA targets. Nucleic Acids Res 48(D1): D127-D131, 2020. PMID: 31504780. DOI: 10.1093/nar/gkz757

28 Rasband WS: ImageJ, US National institutes of health, Bethesda, Maryland, USA, 1997-2018. Available at: https://imagej.nih.gov/ij/ 29 Lee SA, Kim JS, Park SY, Kim HJ, Yu SK, Kim CS, Chun HS, Kim J, Park JT, Go D and Kim DK: miR-203 downregulates Yes-1 and suppresses oncogenic activity in human oral cancer cells. J Biosci Bioeng 120(4): 351-358, 2015. PMID: 25910964. DOI: $10.1016 /$ j.jbiosc.2015.02.002

30 Manikandan M, Deva Magendhra Rao AK, Arunkumar G, Manickavasagam M, Rajkumar KS, Rajaraman R and Munirajan AK: Oral squamous cell carcinoma: microRNA expression profiling and integrative analyses for elucidation of tumourigenesis 
mechanism. Mol Cancer 15: 28, 2016. PMID: 27056547. DOI: 10.1186/s12943-016-0512-8

31 Daige CL, Wiggins JF, Priddy L, Nelligan-Davis T, Zhao J and Brown D: Systemic delivery of a miR34a mimic as a potential therapeutic for liver cancer. Mol Cancer Ther 13(10): 2352-2360, 2014. DOI: 10.1158/1535-7163.MCT-14-0209

32 Van Roosbroeck K and Calin GA: Cancer hallmarks and microRNAs: The therapeutic connection. Adv Cancer Res 135: 119-149, 2017. PMID: 28882220. DOI: 10.1016/bs.acr.2017. 06.002

33 Hou C, Dong Y, Zhang F and Du B: MicroRNA-509 acts as a tumor suppressor in tongue squamous cell carcinoma by targeting epidermal growth factor receptor. Mol Med Rep 16(5): 7245-7252, 2017. PMID: 28944863. DOI: 10.3892/mmr.2017.7531

34 Shiiba M, Shinozuka K, Saito K, Fushimi K, Kasamatsu A, Ogawara K, Uzawa K, Ito $\mathrm{H}$, Takiguchi $\mathrm{Y}$ and Tanzawa $\mathrm{H}$ : MicroRNA-125b regulates proliferation and radioresistance of oral squamous cell carcinoma. Br J Cancer 108(9): 1817-1821, 2013. PMID: 23591197. DOI: 10.1038/bjc.2013.175

35 Fukumoto I, Koshizuka K, Hanazawa T, Kikkawa N, Matsushita R, Kurozumi A, Kato M, Okato A, Okamoto Y and Seki N: The tumor-suppressive microRNA-23b/27b cluster regulates the MET oncogene in oral squamous cell carcinoma. Int J Oncol 49(3): 11191129, 2016. PMID: 27573718. DOI: 10.3892/ijo.2016.3602

36 Umeda M, Yokoo S, Komori T, Nishimatsu N, Shibuya Y and Fujioka M: Experimental model of invasion and metastasis by orthotopic transplantation of oral squamous and adenoid cystic carcinomas into the tongue of nude mice. Br J Oral Maxillofac Surg 39(5): 376-380, 2001. PMID: 11601820. DOI: 10.1054/ bjom. 2000.0590

37 Sanjiv K, Su TL, Suman S, Kakadiya R, Lai TC, Wang HY, Hsiao M and Lee TC: The novel DNA alkylating agent BO-1090 suppresses the growth of human oral cavity cancer in xenografted and orthotopic mouse models. Int J Cancer 130(6): 1440-1450, 2012. PMID: 21500194. DOI: 10.1002/ijc.26142

38 Kamide D, Yamashita T, Araki K, Tomifuji M, Tanaka Y, Tanaka S, Shiozawa S and Shiotani A: Selective activator protein-1 inhibitor T-5224 prevents lymph node metastasis in an oral cancer model. Cancer Sci 107(5): 666-673, 2016. PMID: 26918517. DOI: $10.1111 /$ cas.12914

39 Matsui T, Ota T, Ueda Y, Tanino M and Odashima S: Isolation of a highly metastatic cell line to lymph node in human oral squamous cell carcinoma by orthotopic implantation in nude mice. Oral Oncol 34(4): 253-256, 1998. PMID: 9813718.

40 Wang C, Li S, Xu J, Niu W and Li S: microRNA-935 is reduced in non-small cell lung cancer tissue, is linked to poor outcome, and acts on signal transduction mediator E2F7 and the AKT pathway. Br J Biomed Sci 76(1): 17-23, 2019. PMID: 30203720. DOI: 10.1080/09674845.2018.1520066

41 Wang T, Chen Y, Nie H, Huang Y, Zhao Y and Yang J: IL-27 inhibits non-small-cell lung cancer cell metastasis by miR-935 in vitro. Onco Targets Ther 12: 1447-1454, 2019. PMID: 30863112. DOI: 10.2147/OTT.S173207

42 Yan C, Yu J, Kang W, Liu Y, Ma Z and Zhou L: miR-935 suppresses gastric signet ring cell carcinoma tumorigenesis by targeting Notch1 expression. Biochem Biophys Res Commun 470(1): 68-74, 2016. PMID: 26742429. DOI: 10.1016/ j.bbrc.2015.12.116

43 Liu Z, Li Q, Zhao X, Cui B, Zhang L and Wang Q: MicroRNA-935 inhibits proliferation and invasion of osteosarcoma cells by directly targeting High mobility group box 1. Oncol Res, 2018. PMID: 29471892. DOI: 10.3727/ $096504018 X 15189093975640$

44 Shin J, Shim HG, Hwang T, Kim H, Kang SH, Dho YS, Park SH, Kim SJ and Park CK: Restoration of miR-29b exerts anticancer effects on glioblastoma. Cancer Cell Int 17: 104, 2017. PMID: 29176935. DOI: 10.1186/s12935-017-0476-9

45 Genovesi LA, Carter KW, Gottardo NG, Giles KM and Dallas PB: Integrated analysis of miRNA and mRNA expression in childhood medulloblastoma compared with neural stem cells. PLoS One 6(9): e23935, 2011. PMID: 21931624. DOI: 10.1371/journal.pone.0023935

46 Triozzi PL, Achberger S, Aldrich W, Crabb JW, Saunthararajah $Y$ and Singh AD: Association of tumor and plasma microRNA expression with tumor monosomy-3 in patients with uveal melanoma. Clin Epigenetics 8: 80, 2016. PMID: 27453764. DOI: $10.1186 / \mathrm{s} 13148-016-0243-0$

47 Hummel R, Sie C, Watson DI, Wang T, Ansar A, Michael MZ, Van der Hoek M, Haier J and Hussey DJ: MicroRNA signatures in chemotherapy resistant esophageal cancer cell lines. World J Gastroenterol 20(40): 14904-14912, 2014. PMID: 25356050. DOI: $10.3748 /$ wjg.v20.i40.14904

48 Xu C, Zheng Y, Lian D, Ye S, Yang J and Zeng Z: Analysis of microRNA expression profile identifies novel biomarkers for non-small cell lung cancer. Tumori 101(1): 104-110, 2015. PMID: 25702651. DOI: 10.5301/tj.5000224

49 Sidiropoulos KG, White NM, Bui A, Ding Q, Boulos P, Pampalakis G, Khella H, Samuel JN, Sotiropoulou G and Yousef GM: Kallikrein-related peptidase 5 induces miRNA-mediated anti-oncogenic pathways in breast cancer. Oncoscience 1(11): 709724, 2014. PMID: 25593998. DOI: 10.18632/oncoscience.91

50 Malagobadan S, Ho CS and Nagoor NH: MicroRNA-6744-5p promotes anoikis in breast cancer and directly targets NAT1 enzyme. Cancer Biol Med 17(1): 101-111, 2020. PMID: 32296579. DOI: 10.20892/j.issn.2095-3941.2019.0010

51 Hou BH, Jian ZX, Cui P, Li SJ, Tian RQ and Ou JR: miR-216a may inhibit pancreatic tumor growth by targeting JAK2. FEBS Lett 589(17): 2224-2232, 2015. PMID: 26149212. DOI: 10.1016/j.febslet.2015.06.036

52 Hentschel AE, Nieuwenhuijzen JA, Bosschieter J, Splunter APV, Lissenberg-Witte BI, Voorn JPV, Segerink LI, Moorselaar RJAV and Steenbergen RDM: Comparative analysis of urine fractions for optimal bladder cancer detection using DNA methylation markers. Cancers (Basel) 12(4): 859, 2020. PMID: 32252299. DOI: $10.3390 /$ cancers 12040859

53 Chen ML, Liang LS and Wang XK: miR-200c inhibits invasion and migration in human colon cancer cells SW480/620 by targeting ZEB1. Clin Exp Metastasis 29(5): 457-469, 2012. PMID: 22407310. DOI: 10.1007/s10585-012-9463-7

54 Zhang S, Zhang X, Fu X, Li W, Xing S and Yang Y: Identification of common differentially-expressed miRNAs in ovarian cancer cells and their exosomes compared with normal ovarian surface epithelial cell cells. Oncol Lett 16(2): 23912401, 2018. PMID: 30013629. DOI: 10.3892/ol.2018.8954

55 Yang M, Cui G, Ding M, Yang W, Liu Y, Dai D and Chen L: miR-935 promotes gastric cancer cell proliferation by targeting SOX7. Biomed Pharmacother 79: 153-158, 2016. PMID: 27044823. DOI: 10.1016/j.biopha.2016.01.011

56 Peng B, Li C, Cai P, Yu L, Zhao B and Chen G: Knockdown of miR-935 increases paclitaxel sensitivity via regulation of SOX7 
in non-small-cell lung cancer. Mol Med Rep 18(3): 3397-3402, 2018. PMID: 30066948. DOI: 10.3892/mmr.2018.9330

57 Liu X, Li J, Yu Z, Li J, Sun R and Kan Q: miR-935 promotes liver cancer cell proliferation and migration by targeting SOX7. Oncol Res 25(3): 427-435, 2017. PMID: 27697092. DOI: $10.3727 / 096504016 X 14747300207374$

58 Wang C, Feng Z, Jiang K and Zuo X: Upregulation of microRNA935 promotes the malignant behaviors of pancreatic carcinoma PANC-1 cells via targeting inositol polyphosphate 4-phosphatase type i gene (INPP4A). Oncol Res 25(4): 559-569, 2017. PMID: 27733216. DOI: $10.3727 / 096504016 X 14759554689565$

59 Huang Y, Xiao W, Jiang X and Li H: MicroRNA-935 acts as a prognostic marker and promotes cell proliferation, migration, and invasion in colorectal cancer. Cancer Biomark 26(2): 229237, 2019. PMID: 31524145 . DOI: $10.3233 / \mathrm{CBM}-190183$

60 Po'uha ST, Le Grand M, Brandl MB, Gifford AJ, Goodall GJ, Khew-Goodall Y and Kavallaris M: Stathmin levels alter PTPN14 expression and impact neuroblastoma cell migration. Br J Cancer 122(3): 434-444, 2020. PMID: 31806880. DOI: 10.1038/s41416-019-0669-1

61 Abdi S, Zamanian Azodi M, Rezaei-Tavirani M, Razzaghi M, Heidari $\mathrm{MH}$ and Akbarzadeh Baghban A: Differentiation of $\mathrm{H}$. pylori-negative and positive gastric cancer via regulatory network analysis. Gastroenterol Hepatol Bed Bench 13(2): 161167, 2020. PMID: 32308938.

62 Maxwell GL, Shoji Y, Darcy K, Litzi T, Berchuck A, Hamilton CA, Conrads TP and Risinger JI: MicroRNAs in endometrial cancers from black and white patients. Am J Obstet Gynecol 212(2): 191.e1-10, 2015. PMID: 25174797. DOI: 10.1016/j.ajog.2014. 08.028

63 Wei Y, He R, Wu Y, Gan B, Wu P, Qiu X, Lan A, Chen G, Wang $\mathrm{Q}$, Lin $\mathrm{X}$, Chen $\mathrm{Y}$ and Mo Z: Comprehensive investigation of aberrant microRNA profiling in bladder cancer tissues. Tumour Biol 37(9): 12555-12569, 2016. PMID: 27350368. DOI: 10.1007/s13277-016-5121-z

64 Riazalhosseini B, Mohamed R, Apalasamy YD, Langmia IM and Mohamed Z: Circulating microRNA as a marker for predicting liver disease progression in patients with chronic hepatitis B. Rev Soc Bras Med Trop 50(2): 161-166, 2017. PMID: 28562750. DOI: 10.1590/0037-8682-0416-2016

65 Wilting SM, Miok V, Jaspers A, Boon D, Sørgård H, Lando M, Snoek BC, van Wieringen WN, Meijer CJ, Lyng H, Snijders PJ and Steenbergen RD: Aberrant methylation-mediated silencing of microRNAs contributes to HPV-induced anchorage independence. Oncotarget 7(28): 43805-43819, 2016. PMID: 27270309. DOI: 10.18632/oncotarget.9698.

66 Lui WO, Pourmand N, Patterson BK and Fire A: Patterns of known and novel small RNAs in human cervical cancer. Cancer Res 67(13): 6031-6043, 2007. PMID: 17616659. DOI: 10.1158/0008-5472.CAN-06-0561

67 Wang L, Luo J, Fang M, Jiang G, Zhang X, Yu W and Wang X: A new trick of INPP4A: decreased expression of INPP4A in patients with temporal lobe epilepsy and pilocarpine-induced rat model. Synapse 66(6): 533-541, 2012. PMID: 22422700. DOI: $10.1002 /$ syn. 21540

68 Aich J, Mabalirajan U, Ahmad T, Khanna K, Rehman R, Agrawal A and Ghosh B: Resveratrol attenuates experimental allergic asthma in mice by restoring inositol polyphosphate 4 phosphatase (INPP4A). Int Immunopharmacol 14(4): 438-443, 2012. PMID: 22986054. DOI: 10.1016/j.intimp.2012.08.017
69 Aich J, Mabalirajan U, Ahmad T, Agrawal A and Ghosh B: Lossof-function of inositol polyphosphate-4-phosphatase reversibly increases the severity of allergic airway inflammation. Nat Commun 3: 877, 2012. PMID: 22673904. DOI: 10.1038/ncomms 1880

70 Wang L, Wang Y, Duan C and Yang Q: Inositol phosphatase INPP4A inhibits the apoptosis of in vitro neurons with characteristic of intractable epilepsy by reducing intracellular Ca2+ concentration. Int J Clin Exp Pathol 11(4): 1999-2007, 2018. PMID: 31938306.

71 Sasaki J, Kofuji S, Itoh R, Momiyama T, Takayama K, Murakami H, Chida S, Tsuya Y, Takasuga S, Eguchi S, Asanuma K, Horie Y, Miura K, Davies EM, Mitchell C, Yamazaki M, Hirai H, Takenawa T, Suzuki A and Sasaki T: The PtdIns $(3,4) \mathrm{P}(2)$ phosphatase INPP4A is a suppressor of excitotoxic neuronal death. Nature 465(7297): 497-501, 2010. PMID: 20463662. DOI: 10.1038/nature09023

72 Lin C, Liu A, Zhu J, Zhang X, Wu G, Ren P, Wu J, Li M, Li J and Song L: miR-508 sustains phosphoinositide signalling and promotes aggressive phenotype of oesophageal squamous cell carcinoma. Nat Commun 5: 4620, 2014. PMID: 25099196. DOI: $10.1038 /$ ncomms 5620

73 Zhang W, Qiao B and Fan J: Overexpression of miR-4443 promotes the resistance of non-small cell lung cancer cells to epirubicin by targeting INPP4A and regulating the activation of JAK2/STAT3 pathway. Pharmazie 73(7): 386-392, 2018. PMID: 30001772. DOI: $10.1691 / \mathrm{ph} .2018 .8313$

74 Ijuin T: Phosphoinositide phosphatases in cancer cell dynamicsBeyond PI3K and PTEN. Semin Cancer Biol 59: 50-65, 2019. PMID: 30922959. DOI: 10.1016/j.semcancer.2019.03.003

75 Chaudhuri R, Khanna K, Koundinya D, Pattnaik B, Vatsa D, Agrawal A and Ghosh B: Novel nuclear translocation of inositol polyphosphate 4-phosphatase is associated with cell cycle, proliferation and survival. Biochim Biophys Acta Mol Cell Res S0167-4889(18): 30188-5, 2018. PMID: 30071275. DOI: 10.1016/j.bbamcr.2018.07.013

76 Truesdell SS, Mortensen RD, Seo M, Schroeder JC, Lee JH, LeTonqueze $\mathrm{O}$ and Vasudevan S: MicroRNA-mediated mRNA translation activation in quiescent cells and oocytes involves recruitment of a nuclear microRNP. Sci Rep 2: 842, 2012. PMID: 23150790. DOI: 10.1038/srep00842

77 Duan XM, Liu XN, Li YX, Cao YQ, Silayiding A, Zhang RK and Wang JP: MicroRNA-498 promotes proliferation, migration, and invasion of prostate cancer cells and decreases radiation sensitivity by targeting PTEN. Kaohsiung J Med Sci 35(11): 659-671, 2019. PMID: 31332950. DOI: 10.1002/kjm2.12108

78 Kong J, He X, Wang Y and Li J: Effect of microRNA-29b on proliferation, migration, and invasion of endometrial cancer cells. J Int Med Res 47(8): 3803-3817, 2019. PMID: 31187677. DOI: $10.1177 / 0300060519844403$

79 O'Brien J, Hayder H, Zayed Y and Peng C: Overview of MicroRNA biogenesis, mechanisms of actions, and circulation. Front Endocrinol (Lausanne) 9: 402, 2018. PMID: 30123182. DOI: 10.3389 /fendo.2018.00402

80 Ørom UA, Nielsen FC and Lund AH: MicroRNA-10a binds the 5 'UTR of ribosomal protein mRNAs and enhances their translation. Mol Cell 30(4): 460-471, 2008. PMID: 18498749. DOI: $10.1016 /$ j.molcel.2008.05.001

81 Valinezhad Orang A, Safaralizadeh R and Kazemzadeh-Bavili $\mathrm{M}$ : Mechanisms of miRNA-mediated gene regulation from 
common downregulation to mRNA-specific upregulation. Int $\mathrm{J}$ Genomics 2014: 970607, 2014. PMID: 25180174. DOI: $10.1155 / 2014 / 970607$

82 Vasudevan S, Tong Y and Steitz JA: Switching from repression to activation: microRNAs can up-regulate translation. Science 318(5858): 1931-1934, 2007. PMID: 18048652. DOI: $10.1126 /$ science. 1149460

83 Liao W, Fu Z, Zou Y, Wen D, Ma H, Zhou F, Chen Y, Zhang M and Zhang W: MicroRNA-140-5p attenuated oxidative stress in Cisplatin induced acute kidney injury by activating Nrf2/ARE pathway through a Keap1-independent mechanism. Exp Cell Res 360(2): 292-302, 2017. PMID: 28928081. DOI: 10.1016/ j.yexcr.2017.09.019

84 Kim H, Yang JM, Ahn SH, Jeong WJ, Chung JH and Paik JH: Potential oncogenic role and prognostic implication of microRNA-155-5p in oral squamous cell carcinoma. Anticancer Res 38(9): 5193-5200, 2018. PMID: 30194167. DOI: 10.21873/anticanres. 12842

85 Irimie AI, Ciocan C, Gulei D, Mehterov N, Atanasov AG, Dudea $\mathrm{D}$ and Berindan-Neagoe I: Current insights into oral cancer epigenetics. Int J Mol Sci 19(3): 670, 2018. PMID: 29495520. DOI: $10.3390 /$ ijms 19030670

86 Jing Y, Jin Y, Wang Y, Chen S, Zhang X, Song Y, Wang Z, Pu $\mathrm{Y}, \mathrm{Ni} \mathrm{Y}$ and $\mathrm{Hu} \mathrm{Q}$ : SPARC promotes the proliferation and metastasis of oral squamous cell carcinoma by PI3K/AKT/ PDGFB/PDGFR $\beta$ axis. J Cell Physiol, 2019. PMID: 30706473. DOI: $10.1002 /$ jcp. 28205

87 Wang Q, Lv L, Li Y and Ji H: MicroRNA-655 suppresses cell proliferation and invasion in oral squamous cell carcinoma by directly targeting metadherin and regulating the PTEN/AKT pathway. Mol Med Rep 18(3): 3106-3114, 2018. PMID: 30015840. DOI: 10.3892/mmr.2018.9292
88 Yang Y, Chen D, Liu H and Yang K: Increased expression of lncRNA CASC9 promotes tumor progression by suppressing autophagy-mediated cell apoptosis via the AKT/mTOR pathway in oral squamous cell carcinoma. Cell Death Dis 10(2): 41, 2019. PMID: 30674868. DOI: 10.1038/s41419-018-1280-8

89 Wu J, Wang X, Shang A, Vella G, Sun Z, Ji P, Yang D, Wan A, Yao $\mathrm{Y}$ and $\mathrm{Li} \mathrm{D}$ : PLAC8 inhibits oral squamous cell carcinogenesis and epithelial-mesenchymal transition via the Wnt/ $\beta$-catenin and PI3K/Akt/GSK3 $\beta$ signaling pathways. Oncol Lett 20(5): 128, 2020. DOI: 10.3892/ol.2020.11989

90 Fu X, Wen H, Jing L, Yang Y, Wang W, Liang X, Nan K, Yao Y and Tian T: MicroRNA-155-5p promotes hepatocellular carcinoma progression by suppressing PTEN through the PI3K/Akt pathway. Cancer Sci 108(4): 620-631, 2017. PMID: 28132399. DOI: $10.1111 /$ cas.13177

91 Feng Y, Zheng C, Zhang Y, Xing C, Cai W, Li R, Chen J and Duan Y: Triptolide inhibits preformed fibril-induced microglial activation by targeting the microRNA155-5p/SHIP1 pathway. Oxid Med Cell Longev 2019: 6527638, 2019. PMID: 31182996. DOI: $10.1155 / 2019 / 6527638$

92 Han B, Wang S and Zhao H: MicroRNA-21 and microRNA-155 promote the progression of Burkitt's lymphoma by the PI3K/AKT signaling pathway. Int J Clin Exp Pathol 13(1): 8998, 2020. PMID: 32055277.
Received August 5, 2020

Revised August 30, 2020

Accepted September 3, 2020 